\title{
Cluster policy in Europe and Asia: A comparison using selected cluster policy characteristics
}

\author{
Martina Sopoligová \\ Tomas Bata University in Zlin \\ Crech Republic \\ Email:martina.sopoligova@gmail.com \\ Drahomíra Pavelková \\ Tomas Bata University in Zlín \\ Czech Republic \\ Email:pavelkova@fame.utb.cr.
}

\begin{abstract}
Currently, cluster concept is one of the most important tools for governments to enhance competitiveness and innovations through sectoral specialization and cooperation. The paper focuses on applications of the cluster policy in the distinct territorial context of Europe and Asia so that to perform a comparison between different approaches to the cluster concept application in real practice. The paper introduces a comparative study of the cluster policy concepts based on the characteristics defined by the authors, such as scope, approach, targeting, autonomy, institutional coordination, policy instruments and evaluation system studied for the selected European and Asian countries such as Denmark, France, Germany, China, Japan, and South Korea. The research draws upon processing the secondary data obtained through content analysis of the related literature, government documents and strategies, and also cluster funding programmes. The findings demonstrate the diversity of cluster policies implemented in the context of European and Asian conditions at the current stage of their development.
\end{abstract}

Keywords: cluster policy, characteristics of cluster policy, comparative study, Europe, Asia.

JEL Classification: O18, O32, R11, R58

\section{INTRODUCTION}

Improving the existing economic and social potential of the economy becomes the top priority for most of today's countries. The increased international competition requires new ways to support the development of regions and stimulate their economic growth. The cluster concept, introduced by Michael Porter (1990), is an instrument for governments that enables enhancing the competitiveness of regions and thus, of the entire country. Porter (1990) defined cluster as a spatially concentrated, interacting combination 
of companies with funding organisations and public agencies acting to develop them. All "efforts of government to develop and support clusters in a particular region" (Hospers \& Beugelsdijk, 2002, p. 382) may be generally defined as the cluster policy. In the 1990s, the evidence of advantages generated by clusters prompted national and regional governments in most countries to introduce cluster development policies so that to generate new sources of competitiveness for their territories (Saublens, 2007; Ketels et al., 2006).

The cluster concept is widely spread in Western Europe and North America and is increasingly popular in less developed parts of the world, including South Asia and Sub-Saharan Africa. Clusters in developing countries differ from those in developed regions, at least in the following aspects: the dynamics of development, organisational setup, geographical distribution and position within the global value chain (Chaminade \& Vang, 2006).

The scale at which cluster policies are designed also varies from country to country and depends on political structure, size and resources of a country (Boekholt \& Thuriaux, 1999).

In literature there can be found many studies trying to define cluster policy using different approaches to its implementation (Saxenian, 1994; Feldman, 1999; Roelandt et al., 1999; Fromhold-Eisebith \& Eisebith, 2005). Others examine cluster policy according to their location through variety of characteristics (Kiese \& Hundt, 2014; Borras \& Tsagdis, 2008; Oxford Research AS, 2008). There has been also a number of papers to evaluate the specific policies toward clustering in the EU countries (Borras \& Tsagdis, 2008; Hendry, Brown \& Defillippi, 2000; Lenchuk \& Vlaskin, 2010; Sternberg, Kiese, Stockinger, 2010), while others juxtapose cluster-related policies within Asian regions (Andersson, Serger, Sorvik \& Hansson, 2004; Chaminade \& Vang, 2006; Das, 2008; Fujita, 2007; Ganne \& Lecler, 2009; Kuchiki, 2005; Mazurek, 2014). Mazurek (2014) describes differentiation of cluster policies in the selected Asian coutries by a set of characteristics: „parent“ policy, definition of a cluster, role of the government, level of governance, policy target, and policy goals. Moreover, some recent studies empirically evaluate cluster policies within regions of a single country, as e.g. for Germany (Kiese \& Hundt, 2014) and for France (Fontagné, Koenig, Mayneris \& Poncet, 2013).

However, only a small number of studies provide comparison of the approaches to cluster policies in Asian and European countries at the same time (Okamuro \& Nishimura, 2015; Pessoa, 2012). The study of Okamuro and Nishimura (2015) shows that national cluster policies considerably differ among European and Asian countries by their basic conditions of clusters' functioning and differences caused by various regional characteristics. Pessoa (2012) compared cluster policies in the OECD and Asian countries using two features: the approach to cluster policy and the role of the government.

Due to the lack of deeper studies on cluster policy issues in the distinct territorial context, this paper focuses on applications of the cluster policy and gives more detailed comparison of cluster policies' approaches in Europe and Asia. For this purpose, more characteristics of cluster policy had been defined by the authors and further used for the comparison of European and Asian approaches to cluster policies, applying them on the selected countries from both regions. The research is therefore focused on six countries: Denmark, France, Germany, China, Japan, and South Korea. These countries were picked out for two major reasons. First, they have all promoted clusters using national or regional policies by investing significant public funds within more or less defined institutional framework. This selection of countries was meant to create structural and institutional variety for international comparison of cluster policies. Secondly, they all are among the leading nations in terms of innovations. According to the European Innovation Scoreboard 2016 (EC, 2016), Denmark and Germany are innovation leaders and their level of innovation performance is above the EU average (Denmark - 34\%, Germany - 21\%; as of in 2015). France is a strong innovator with its innovation performance level being at 9\% above the EU average in 2015. South Korea 
and Japan have their performance level higher than the EU average and along with China are EU's main competitors in innovation performance (EC, 2016).

The research draws upon a critical review of the literature presented in Chapter 2 and the study of documents and strategies of cluster-related responsible bodies and their websites, cluster funding programmes, which help the cluster policies to be implemented, described in the methodological part in Chapter 3. The research methodology also contains the characterictics defined by the authors for describing the features of cluster policies. Development of cluster policies in Europe and Asia, followed by the description of individual cluster policies in the selected countries using the defined characteristics, are introduced in Chapter 4. Discussion of differences and similarities in both these regions is presented in Chapter 5, followed by the conclusion in Chapter 6 with the summary of findings and a proposal for further possible research on this topic.

\section{THEORETICAL BACKGROUND AND LITERATURE REVIEW}

In the nineties of the last century, Porter introduced the idea that policy activities can trigger the development of clusters and, thus improve regional growth and increase competitiveness (Porter, 2008). After the introduction of the cluster concept, many national and regional governments set up strategies and programmes to support clusters (Sölvell et al., 2003).

Cluster policies began to be implemented in the early 1990's when pioneer countries and regions tried to develop competitiveness and innovation using the cluster concept. World practice shows that during the last two decades clustering has occurred extensively. The European Cluster Observatory in the quantitative analysis of European clusters identified more than 3000 strong clusters employing $45 \%$ of the European workforce, what constitutes 54 million jobs (EC, 2016). The process of cluster formation is actively going on in Asian countries. In particular, in China more than 60 special cluster zones with 3,5 million workers were identified (Lenchuk \& Vlaskin, 2010). The report provided by the EU-Japan Centre (2016) suggests that at least 52 clusters operated in Japan in 2016.

In terms of this extensive growth, interpretations of the cluster policy concept are diverse. It can be manifested by a range of policies encouraging low-resourced, small-group business networks without a particular focus on complex or large-scale programmes targeting a specific industry (Raines, 2001). These different policies consider a "cluster" in different terms of its sectoral breadth, density, economic value to the surrounding economy and its competitiveness (Enright, 2000).

In a broad sense, cluster policy can be understood as a support of a government, alone or in a collaborative effort with companies, universities, and others, that are directed at clusters to increase their competitiveness (Ketels, 2009). Pavelková et al. (2013) define cluster policy as a set of various activities focused on obtaining a concrete aim, in this case increasing socio-economic benefits thanks to the establishment and development of a cluster. Those activities are usually being implemented according to a plan and a budget devoted to clusters.

Available literature on cluster policy identifies different cluster policy models. As described by the European Commission (2005, p. 10), "clusterpolicy is not an isolated, independent and well-defined discipline. It embraces all policies that affect the development of clusters... Many policies labelled under different headings (regional policy, industrial policy, innovation policy, etc.) are in fact cluster policies..." Ketels (2009, p. 27) also emphasises "the design of cluster policy programmes and their integration in a broader economic policy agenda are crucial for the impact cluster policy can achieve".

Studies devoted to clusters pursue a variety of characteristics to compare cluster policy profiles. Enright (2000) points out distinct similarities and differences in cluster-related policies: improving the generalised business environment, providing information and data, providing infrastructure, education, and training, 
fostering inter-firm networking and collaboration, providing business services, investing or business attraction policies and foster community building. As he further claims, distinct differences in cluster policies are the following: definition of clusters, a level of government, nature of involvement, an origin of the base, cluster selection, "market failures".

In terms of support cluster development, there may be used different forms of financial resources. In addition to private resources mostly in forms of regular membership fees of cluster members, Skokan et al. (2012) distinguish open-end and temporary public financing which is expected after 3 to 5 years of cluster operations.

Kiese (Kiese \& Hundt, 2014) developed a multidimensional model of cluster policy based on work of Fromhold-Eisebith \& Eisebith (2005). The model consists of the following dimensions: cluster reference, coherence, complexity, institutionalisation, cluster orientation and maturity.

In contrast to Western Europe and North America, the transition economies in Central and Eastern Europe, and East Asia display specific weaknesses in institutional conditions of cluster policy framework (Batra et al., 2003).

Mazurek (2014) has made a comparison of cluster policy approaches within Asian countries using examples of the Knowledge Clusters in Japan, the Specialized Towns Programme in China, provincial cluster development policy in Thailand, craft villages in Vietnam and Micro and Small Enterprises - Cluster Development Programme in India. He used the following characteristics for the description of the following approaches: the definition of clusters, the role of government, the level of governance, policy targets, and policy goals.

According to The Whitebook (Andersson, Serger, Sorvik \& Hansson, 2004), cluster policies promote a variety of economic and social objectives. The Danish government belongs to countries with strong focus on supporting small and medium-size enterprises (SMEs). France and Germany have strong cluster programmes addressing human capital and innovation issues connected to clustering. China has implemented cluster policy related to science parks and incubators to enhance innovation objectives.

Polozhentseva and Klevtsova (2015) have formed and compared two basic models of cluster policy implementation: a model of state regulation and liberal model. While within the first model, an active state plays a major role, the liberal model considers the cluster as an element of the market. State regulation is most common, for example, in Japan, South Korea, Sweden, France, Finland and Slovenia. The role of the government is to remove barriers to cluster development and can be found in cluster-based policies in the US, the UK, Australia and Canada.

According to Kuchiki (2005), the flowchart approach posits that cluster policy can be effective in forming clusters by establishing industrial zones, building capacity, and inviting anchor companies. Kuchiki (2005) illustrated this approach on successful cluster policy in China, where two Japanese companies Canon and Toyota functioned well in the clusters as the "anchor companies".

Roelandt et al. (1999) distinguished bottom-up and top-down models of cluster policy. According to their findings, a top-down approach is a model of explicit cluster policy, implemented by regional authorities. On the contrary, implicit initiatives emerge from a bottom-up approach initiated by groups of sector-related companies without a concrete political impulse.

Several studies compare cluster policies implemented in Asia with cluster approach used in other regions. Atanasova (2014) reveals the experience in the development and implementation of cluster policy by considering three types of models: the American model, the Asian model, and the European model. This division is based on approaches to creation and promotion of clusters, which stem from specifics of economic development and traditions of regions. The American model is characterised by the high level of relations between companies, research centres, and universities. The Asian model is distinctive of active 
government support for the creation of conditions for the cluster development. The model is based on the cluster approach mainly implemented in Japan and China, even though it is actively implemented also by other Asian countries (India, Indonesia, Malaysia, Kazakhstan, etc.) and hundreds of new technoparks with research institutions have been established. According to Atanasova (2014), the European model ensures economic success through the development of centres of excellence. The EU and its member states developed cluster strategies including initiatives to encourage transnational clusters, which facilitates access of clusters to new markets.

Ketels (2015) highlights differences between the Western model and the Asian model of cluster policy. The cluster policy in Western regions is more market-driven with a focus on framework conditions. On the other hand, the Asian countries use the model led more by a government with a focus on specific industries.

Okamuro and Nishimura (2015) have provided a comparison of national cluster policies in Europe and Asia. Based on their findings, cluster policy in Asian countries can be regarded as typical low-incentive policy accompanying the top-down selection of targeted clusters with a full funding scheme. European countries are characterised by high-incentive policy based on hard competition among clusters with a complete matched funding scheme.

The findings of comparative analysis carried out within Asian and OECD countries (Pessoa, 2012) characterise Asian cluster policy more effective in creating and supporting clusters than the approaches to the cluster-based policy within OECD countries. It could be achieved due to "a flowchart approach" (Kuchiki, 2005), where all procedures and incentives are formalized, and due to the creation of sufficient conditions for cluster development. In OECD countries, "a laissez faire" approach of the government is preferred.

\section{METHODOLOGICAL FRAMEWORK}

To achieve the main goal of this research, detailed information of approaches to cluster policy was required. Secondary data for description and comparison of cluster policies were obtained using a qualitative research based on critical review of available papers, books, documents and strategies, government decrees, studies and cluster funding programmes, which help the cluster policies to be implemented.

For the research, the theory of comparative study was used. However, there is a little discussion whether the comparative method should be considered as a methodology (Hantrais, 2009). According to Landman (2008), classifications help to simplify the complexity that emerges from the contextual description by grouping entities into simpler categories. A first step in selecting relevant countries may be narrowing the field to countries in particular region. As the study deals with the cluster policy concept within European and Asian countries, three examples from each region were selected.

The analysis of development and current situation in the individual countries was carried out. The unified methodology of the research was applied in each of the country covering the level of governments and agencies supporting clusters development.

The secondary data for research had been collected employing government strategic documents content analysis and utilizing statistical data concerning financial support (existing programmes).

The scope of the analysis was defined as follows:

i) Existing/valid documents concerning the cluster policy implementation, their types (policy decree, programme, methodology, etc.).

ii) Existing responsible implementing bodies (ministries, national/regional authorities and development agencies), cluster supporting institutions and universities/research institutes.

iii) The description of the existing funding programmes: 
- their independency or being part of other policies,

- thematic focus,

- the amounts of the programme financial allocations,

- system of competition for funding.

iv) The system of cluster evaluation.

\subsection{Cluster policy characteristics}

Drawing on literature reviews and authors experience, following set of characteristics for description and comparison of cluster policies were been developed by authors: 1) scope, 2) approach, 3) targeting, 4) autonomy, 5) institutional coordination, 6) policy instruments, and 7) evaluation system. The descriptions of these characteristics are following.

\section{Scope}

Policy strategies toward clusters can differ in the nature of the government involvement and intervention. Governmental efforts can come from the national or regional levels (Fromhold-Eisebith \& Eisebith, 2005; Hospers \& Beugelsdijk, 2002; Oxford Research AS, 2008). The scope is related to the operation of policy on documents/programmes on the national or the regional level. To answer this question searching of the existing cluster policy documents, strategic plans, policy papers, as well as all main political statements with respect to clusters was needed. The cluster policy strategy is implemented through cluster programmes with different structure and design at the national and/or the regional level.

\section{Approach}

The approach to cluster policy depends on the policy involvement. It may be the bottom-up approach, characterised by strong involvement by the private cluster actors, better suited to activating cluster members and strengthening the identification with the cluster; within this approach cluster emerge due to an initiative of groups of parts of the Triple Helix model, i.e. university, industry, and government (Leydesdorff, Etzkowitz, 1998) without a concrete political impetus; the top-down approach refers to the measures to support clusters initiated by the government and fits better to new clusters characterised by a lack of material assets, entrepreneurs, and cooperation (Fromhold-Eisebith \& Eisebith, 2005); clusters emerge as a result of the activities of public policy, and the mixed approach as a combination of both topdown and bottom-up model (Hendry, Brown, Defillippi, 2000).

\section{Targeting}

The targeting refers to the question that is affected by the policy. Cluster policy may cover all sectors and industries or may be limited to certain sectors or areas, or supports only one selected sector or area (Andersson, Serger, Sorvik \& Hansson, 2004; Raines, 2001). The targeting examines a degree of covering places (leading regions, lagging regions), sectors (KET, nanotechnology, machinery, biotechnology, etc.), specific actors (universities, SMEs) - in some cases, actors may be targeted by policy for behaviour change, or areas (e.g. stimulation of regional economies, strengthening international competitiveness, building communities, giving more space to research).

\section{Autonomy}

This characteristic means, in other words, the existence of separate cluster policy. It examines whether the policy documents or strategies are exclusively devoted to cluster support; there exist documents or programmes fully focused on clusters. Cluster policy can be a part of another, a broader or similar policy with a corresponding proportion of the cluster policy focus, or clusters are only generally mentioned in some strategies or documents without other specifications. In most countries, cluster policy is not a separate element of policy. It may play a role as a framework in a number of policy areas (Oxford Research AS, 
2008), e.g. research and innovation policy, industrial policy, business network policy, export policy, science and education policy, SME supporting policy, regional development policy.

\section{Institutional coordination}

Given the heterogeneity of clusters, a prerequisite for successful cluster policy is the existence of an institutional coordination. Uncoordinated policy measures might result in a reduced effectiveness of cluster policy actions and a waste of public resources (Coniglio et al., 2011). This aspect is incorporated in the institutional coordination characteristic examines institutional framework, i.e. supporting organisations and policy coordination. It describes the way that nations provide a strong unifying approach that supports policy guided by the governmental strategic plan. Institutional framework has a key influence on the shape and direction taken by cluster policies; it varies from a dominant ministry in place that has the explicit power to set national objectives to no formal coordinating framework in place (Nauwelaers, 2001). The institutional coordination is connected with the existence of a governance body. Thus, the following may exist in a country: the government body - primary ministry responsible for cluster policy implementation, additional ministries supporting clusters in specific sectors, an institution exclusively established for cluster policy, an intervening agency responsible for supporting clusters, and an institution responsible for supporting cluster policy at the regional level.

\section{Policy instruments}

Cluster policy combines different instruments to support cluster development. This characteristic examines the presence of direct or indirect support for clusters. The direct financial support may be carried out by support programmes accomplished through subsidies, grants, voucher schemes and loans (direct). Or it can be implemented indirectly by creation of networks or coordination support. Financial support is different in the amount of financial sources, budget limits per project, the number and frequency of calls, the number of supported projects, etc. The differences between direct (primarily financial) and indirect (meetings, events) support indicate the conditions necessary for the effective organisation of cluster policies (Okamuro \& Nishimura, 2015). Active communication among cluster participants leads to higher productivity of innovation activity in the region (Fujita, 2007).

\section{Evaluation system}

This characteristic investigates the cluster evaluation system. The generally recognised and accepted cluster evaluation mechanism is a feature of system approach to cluster policy. The evaluation process should be open and transparent, applicable to any cluster (Kind, Meier zu Köcker, 2011), evaluating the capability of clusters by selected parameters. The most common models are as follows: the national accreditation scheme for clusters, the national categorising system, or the system of labelling. The system of cluster evaluation based on various criteria could support selection processes of clusters within cluster support programmes (Fontagné et al., 2013).

\section{CLUSTER POLICIES DEVELOPMENT IN EUROPE AND ASIA}

No set of cluster policies is applied uniformly in different economies and regions. The following sections examine European and Asian cluster policies, according to the above-mentioned characteristics to illustrate the diversity of implemented cluster policies.

\subsection{Development of cluster policies in Europe and Asia}

Europe is a home to a large number of cluster policies with a high degree of heterogeneity. European clusters may be less prominent than the American ones, such as those in the Silicon Valley, for example, but that does not mean that Europe does not have success stories. The approaches to cluster-based policies 
are diverse due to the base of different business environments, cultural frameworks as well as their different implementations. The conditions related to economics and innovation are subject to constant change. Recently, many European countries have evolved their cluster strategies and most of the programmes are now more complex. But, there are still a few European countries without cluster programmes and some clusters do not have the necessary critical mass and innovation capacity to face international competition (European Communities, 2008). European clusters are greatly supported by the European Union (EU), which has resulted in the establishment of a number of programmes and initiatives (the PRO INNO Europe, the Europe INNOVA initiative, the Regions of Knowledge, the European Cluster Alliance, the European Cluster Excellence Initiative, the European Cluster Policy Group, and the European Cluster Collaboration Platform). The European Commission (EC) has published papers aimed at encouraging members to integrate clusters in their national programmes (the European Cluster Memorandum, the Cluster Management Guide, the Smart Guide to Cluster Policy). The very important factor is a sizeable financial support for innovation and regional policy from the EU funds. Another significant support for clusters is the mapping of geographical concentration of economic activities within EU countries (the European Cluster Observatory - a biannual European Cluster Panorama1).

Increasing clustering has been recently observed in Asia, as the result of various factors. First, there is a long industrial tradition in Asian countries; therefore, specialised industries concentrate naturally. Second, there are many small and medium-sized companies as a result of the craft tradition. They represent a sizeable part of the economy and have a huge impact on the market through the creation of clusters. Third, Asian countries are attractive to foreign direct investment, which has resulted in the creation of many new businesses. Moreover, Asian governments have great power and provide huge support for clusters and cluster initiatives (Das, 2008). According to Okamuro \& Nishimura (2015), some governments in Asia initiated cluster policy strongly influenced by European policies (e.g. Japanese government in 2001).

\subsection{Cluster policies characteristics in selected countries on European and Asian territories}

Table 1 demonstrates cluster policy in Denmark, France, and Germany as representatives of European territory and Table 2 cluster policy in China, Japan, and South Korea. The characteristics defined in methodological part suggested by authors have been used to emphasize important features of cluster policies and to enable to discuss the differences between these regions.

The European countries investigated in this paper, Denmark, France, and Germany are interesting for at least two reasons. First, they have long traditions of strong government intervention regarding the locations of economic activities. Second, they have different approaches to implementation of the cluster concept. In Germany, the most relevant cluster initiatives are taken not at the federal but at the regional level of the "Länder". France and Denmark have national cluster policies that support national and regional clusters. Clusters situated in Germany show a great variability; generally, two key types of clusters can be distinguished there. On the one hand, there are so-called bottom-up clusters which are industry driven and have no significant political control. On the other hand, there are so-called top-down clusters initiated and controlled by politics. Both types of clusters are very successful (Meier zu Köcker et al., 2010). Unlike German clusters, cluster initiatives across France are unified and make use of the same general framework (Duranton, 2011). In Denmark clusters operate within national innovation networks, which build bridges

\footnotetext{
${ }^{1}$ https://ec.europa.eu/growth/industry/policy/cluster/observatory/cluster-mapping-services/cluster-panorama
} 
between knowledge institutions and especially SMEs. The innovation networks are supported by the Ministry of Higher Education and Science, whereas the other clusters are typically supported by regions or municipalities.

The process of cluster formation is actively going on in Asia; nevertheless, the region is traditionally more focused on global markets than on regional integration (Ketels, 2015). According Mazurek (2014, p. 61) "Asian cluster policies are as diversified as the Asian economies". The developing process is more heterogeneous with many differences: the emergence of new clusters in China; the development of new hubs of competitiveness and the creation of knowledge clusters in Japan and mini-clusters in South Korea (Ganne \& Lecler, 2009). In South Korea, until today, about 60 so-called mini-clusters have been initiated and labelled by a top-down approach. Due to this state-driven implementation, structures, objectives and working methods of all mini-clusters are very similar (Meier zu Köcker et al., 2010).

However, some factors are common in China, South Korea, or Japan, such as the long history of production in small towns. The clusters are organised around a large-scale production based on the transnational corporation (Meyer-Stamer, 1998) and include many small companies.

\section{DISCUSSION OF THE RESULTS}

The comparison of cluster polices presented above demonstrates that there exists a range of different approaches. This paper contrasts cluster policy in European and Asian regions using defined characteristics, which help to describe the way how cluster concepts are implemented and allow comparison. To illustrate a variety of cluster policies, several countries from each continent were chosen for closer investigation: Denmark, France, and Germany from Europe and China, Japan, and South Korea from Asia. Cluster policies in selected countries that are subject of the present study are characterised by the existence of certain features specific to each country studied. It is not easy to depict common features of "European cluster policy" and "Asian cluster policy", but some commonalities in terms of defined characteristics can be observed.

According to the scope of cluster policy, European cluster policy is implemented at the national and/or regional levels, even though regional cluster programmes are less common. In Asia, cluster policies are implemented by national government with the cooperation of local government and strongly supported by state funded programmes. The great involvement of the public authorities is evident.

Clusters in Europe are financially supported by a state budget or by EU funds. The leading approach in Europe is bottom-up, to fit the needs of industries while removing market imperfections. Regarding the role of the government, "a laissez-faire" approach is nowadays preferred in European countries. Asian countries express a notable preference for the top-down approach with a multitude of policy interventions; from setting national priorities, formulating a vision for the future, and inviting anchor companies to promote competition. These different approaches result in different structure of clusters in Europe and Asia. European clusters are more heterogeneous; they are developed organically, or they are initiated and controlled by politics or business development agencies. Asian clusters have very similar structure due to great involvement of governments in cluster policy, as this study of selected Asian countries demonstrates.

When comparing cluster policies in Europe and Asia, it can be argued that cluster policies are most different within its targeting. The cluster policies in selected countries in Europe target to building networks, developing of strong and excellent clusters, enhancing cooperation between the public and private sector and promoting innovation. In Asian countries, clusters serve mainly as a tool for establishing the basic infrastructure to narrow the regional gaps or on the other hand encourage the development of highly specialised towns. 
In the context of autonomy, all selected countries implement the cluster concept with strong government support and as a part of government policies. Cluster support is implemented mainly within industrial, technology and innovation policies (no exclusive cluster policy) on both of the continents.

In all examined countries, cluster policy is implemented within the institutional framework providing support services. Government bodies responsible for the formulation of cluster policy are mostly ministries (ministry of science, innovation, economy, industry, education, or tourism); the government involvement may be a guarantee of cluster policy sustainability.

There is an existence of considerable public financial support in all analysed countries implemented by using different cluster programmes. The approaches to selection of beneficiaries differ. The French government has successfully implemented two essential but different programmes supporting clusters. Compared to the first cluster policy programme (LPS), which funded projects and not directly a group of firms, the current competitiveness cluster scheme is ambitious and fairly costly (Table 1). Cluster funding is based on the selection of clusters by the national authorities. Companies in these "national" clusters export more than do others (Fontagné et al., 2013). Within ICP in Japan, METI has selected regional clusters based on comparative advantages. Cluster programmes in Germany, France, and Denmark are mainly based on applications or appointments. Financial aid to clusters is accompanied by the different degree of indirect cluster support as networking or training activities. The analysed European cluster policies, the provided public support are mainly related to R\&D support. In Asia, the state aid refers to building infrastructure, $R \& D$ activities, and includes mainly grants to firms, loans and tax incentives.

Gaining greater importance of cluster policies, evaluation of clusters is being more inevitable. In both continents, cluster policy financial support scheme has tended to emphasise on competition for the selection of cluster projects. An evaluation of the BioRegio programme (Germany) or Les Pôles de compétitivité (France) may be served as a model for other programmes in Europe and Asia. Besides assessment of clusters to obtain financial support within cluster programmes, the accreditation schemes or labelling is supportive for international visibility of clusters. The majority of countries have the evaluation concept implemented in their cluster policy: "Innovative Cluster Company" and "Les Pôles de compétitivité" in France, "Kompetenznetze Deutschland" in Germany, "Specialised Town" in China, "Mini-clusters" in South Korea.

Useful experiences exist in Asian countries that open up broad scope for promoting clusters based upon local resources. The strategy, "one product per village and one sector per town" in China provides clues that are being considered in intervening in other economies as well, e.g. in economies with poor export performance. As Das (2008) emphasises, an important point in this approach is a strong emphasis on ensuring product quality through certification. Many of these products are being marketed domestically and globally. According Zeng (2011), special economic zones in China, with the numerous industrial clusters, have contributed significantly to national GDP, employment, exports, and attraction of foreign investment. China's model of clusters adapted mostly locally offers very useful experiences and lessons for other developing countries.

\section{CONCLUSION}

To return to the purpose of this study, an examination of ways by which cluster policy has been implemented in different European and Asian countries, some conclusions can be drawn. It can be argued that cluster policy has progressed much further in Europe than in Asia and in some aspects developed rather differently. A reason can be the difference in purpose of cluster policy implementation and the way of cluster 
support. Nevertheless, disparities in economic development, social structures, and political systems are much greater in Asia than Europe.

The research findings identified similarities regarding the ambitions of governments in supporting clusters regardless of the existence of exclusive cluster policy in any of the examined countries. The findings of the research do not recommend which model of cluster policy should be preferred, there is no one-sizefits-all approach. By comparing the cluster policies based on defined characteristics, it was possible to identify aspects which are nessesary to be taken into account within each approach. In European countries cluster policy is implemented from the point of view of bottom-up approach. The clusters have been created mainly upon the initiative of the private sector. Cluster policies in Asian countries may be characterised as top-down approach with the more crucial role of the local government.

The main result of the study may be lessons how selected countries in Europe and in Asia access to organisation and implementation of their cluster policy and which cluster policy elements are important for cluster policy to work. Each country needs to make cluster policy practical and adapts strategies to its unique economy. To find the optimal approach is one of the greatest challenges for national or regional governments. This knowledge may be useful for a country that has decided to create new cluster policy or revise existing cluster policy or cluster programme.

The research presented here has some limitations. Within the scope of this Europe-Asian related study, it is not possible to make a comprehensive overview of all cluster-related policies. In the future research more or some different above-mentioned characteristics for evaluation of cluster policies can be used, and more focused view on the impact of different approaches on national and regional competitiveness can be applied.

\section{ACKNOWLEDGEMENT}

The authors are thankful to the Internal Grant Agency of Faculty of Management and Economics, Tomas Bata University in Zlín, No. IGA/FaME/2015/0036 "The impact of the concept of cluster policy on the establishment and the viability of cluster companies", for financial support to carry out this research.

\section{REFERENCES}

Adamowicz, M., \& Machla, A. (2016). Small and Medium Enterprises and the Support Policy of Local Government. Oeconomia Copernicana, 7(3), 405-437. Retrieved from http://dx.doi.org/10.12775/OeC.2016.024.

Andersson, T., Serger, S. S., Sorvik, J., \& Hansson, E. W. (2004). The Cluster Policies. Sweden: Whitebook: IKED.

Atanasova, A. V. (2014), ЧУЖАЕСТРАННИЯТ ОПИТ В СЪЗААВАНЕТО НА КАЪСТЕРИ [Foreign Experience in Clusters Formation]. Икономика и Уиравление, X, 1. [In Bulgarian].

Batra, G., Kaufmann, D. \& Stone, A. H. W. (2003). The Firms Speak: What the World Business Environment Survey Tells us about Constraints on Private Sector Development, Working Paper, World Bank.

Boekholt, P., \& Thuriaux, B. (1999). Boosting innovation: the cluster approach. Paris: OECD Publications.

Borras, S., \& Tsagdis, D. (2008). Cluster Policies in Europe. Firms, Institutions, and Governance; E. Elgar: Cheltenham, UK.

Coniglio, N., Prota, F., \& Viesti, G. (2011). Promoting industrial clusters in Vietnam: a proposal. PROJECT TEVIE08003, Bari.

Chaminade, Ch., Vang, J. (2006). Innovation Policy for Asian SMEs: Exploring Cluster Differences. DRUID Summer Conference 2006 on Knowledge, Innovation and Competitiveness: Dynamics of Firms, Networks, Regions and Institutions. Copenhagen, Denmark, June 18-20, 2006.

Das, K. (2008). Fostering competitive clusters in Asia: towards an inclusive policy perspective. Chiba: Institute of Developing Economies. Retrieved from https://www.researchgate.net/publication/242657674 Fostering Competitive Clusters in Asia Towards an Inclusive Policy Perspective

Duranton, G. (2011). California Dreaming: The Feeble Case for Cluster Policies. Review of Economic Analysis, 3(1), 3-45. 
Enright, M. (2000). The globalization of competition and the localization of competitive advantage: policies towards regional clustering in Hood, N. and Young, S. (ed.) Globalization of Multinational Enterprise Activity and Economic Development, Macmillan, London.

EU-Japan Centre. (2016). Report: Cluster Mapping in Japan 2016. Retrieved from http://www.eubusinessinjapan.eu/library/publication/report-cluster-mapping-in-japan-2016.

European Commission. (2016). Center for Strategy and Competitiveness. Stockholm School (Rep.). (n.d.).

European Commission. (2016). European Innovation Scoreboard 2016. Retrieved from http:/ / ec.europa.eu/growth/industry/innovation/facts-figures/scoreboards/index en.htm.

European Commission. (2005). Final report of the Expert Group on Enterprise Clusters and Networks. Belgium, 2005.

European Communities. (2008). Towards World-Class Clusters in the European Union: Implementing the Broad-Based Innovation Strategy, 652.

Feldman, M. P. (1999). The new economics of innovation, spillovers and agglomeration: a review of empirical studies, Economy Innovation New Technology, 8, 5-25. doi:10.1080/10438599900000002.

Fontagné, L., Koenig, P., Mayneris, F., \& Poncet, S. (2013). Cluster policies and firm selection: evidence from France, Journal of regional science, 53(5), 897-922.

Fromhold-Eisebith, M., \& Eisebith, G. (2005). How to institutionalize innovative clusters? Comparing explicit topdown and implicit bottom-up approaches. Research policy, 34(8), 1250-1268.

Fujita, M. (2007). The development of regional integration in East Asia: from the viewpoint of spatial economics, Review of Urban and Regional Development Studies, 19, 2-20.

Ganne, B., \& Lecler, Y. (2009). Asian industrial clusters, global competitiveness, and new policy initiatives. Singapore: World Scientific.

Hantrais, L. (2009). Combining Methods in International Comparative Research. International Comparative Research, $95-$ 117. doi:10.1007/978-1-137-06884-2_5.

Hendry, C., Brown, J., \& Defillippi, R. (2000). Regional clustering of high technology-based firms: opto-electronics in three countries. Regional Studies, 34(2), 129-144.

Hospers, G., \& Beugelsdijk, S. (2002). Regional Cluster Policies: Learning by Comparing? Kyklos, 55(3), $381-402$. doi:10.1111/1467-6435.00192.

Ketels, C. (2015). Clusters for Competitiveness: Mobilising the Power of Modern Cluster Policy. $18^{\text {th }}$ TCI Global Conference, Daegu, South Korea.

Ketels, C. (2009). Clusters, Cluster Policy, and Swedish Competitiveness in the Global Economy. Expert Report no. 30 to Sweden's Globalisation Council. Västerås: PRINT Edita. ISBN 978-91-85935-29-1.

Ketels, C., Lindqvis, G., \& Sölvell, O. (2006). Cluster Initiatives in Developing and Transition Economies. Center for Strategy and Competitiveness, Stockholm. (Rep.). (n.d.).

Kiese, M., \& Hundt, C. (2014). Cluster Policies, Organising Capacity and Regional Resilience: Evidence from German Case Studies. Raumforschung und Raumordnung, 72(2), 117-131. doi:10.1007/s13147-014-0282-y.

Kind, S., \& Meier zu Köcker, G. (2011). Evaluation concept for clusters and networks. Prerequisites of a common and joint evaluation system. Working paper des Instituts für Innovation und Technik in der VDI/VDE-IT, Nr. 07, Berlin.

Kuchiki, A. (2005). Theory of the Flowchart Approach to Industrial Cluster Policy, in: Kuchiki, A. and Tsuji, M. (Eds.), Flowchart Approach to Industrial Cluster Policy in Asia, Institute of Developing Economies - JETRO, Tokyo.

Landman, T. (2008). Issues and Methods in Comparative Politics: an introduction; 3rd ed. London, New York: Routledge, doi:10.4324/9780203929780.

Lenchuk, E. B., \& Vlaskin, G. A. (2010). The cluster approach in the innovation development strategy of foreign countries. Studies on Russian Economic Development, 21(5), 484-492. doi:10.1134/s1075700710050047.

Leydesdorff, L., \& Etzkowitz, H. (1998). The Triple Helix as a model for innovation studies. Science and Public Policy, 25(3). doi:10.1093/spp/25.3.195.

Mazurek, S. (2014). Diversity of cluster policies in Asian countries. Prace Naukowe Uniwersytetu Ekonomicznego we Wroctawiu, (370). doi:10.15611/pn.2014.370.04

Meier zu Köcker, G., Garnatz, L., Kergel, H. (2010). Clusters in Gemany and Korea - Similarities and Differences. Retrieved from http://www.archive.clustercollaboration.eu. 
Meyer-Stamer, J. (1998). Avoiding Collective Efficiency. Growth and Crisis in the Furniture Cluster in SãoBento do Sul (Santa Catarina, Brazil), mimeo. Duisburg.

Nauwelaers, C. (2001). Path-Dependency and the Role of Institutions in Cluster Policy Generation. Cluster Policies Cluster Development? Edited by Åge Mariussen. Stockholm 2001. (Nordregio Report 2001:2).

Okamuro, H., \& Nishimura, J. (2015). Local Management of National Cluster Policies: Comparative Case Studies of Japanese, German, and French Biotechnology Clusters. Adm. Sci., 5, 213-239, doi:10.3390/admsci5040213.

Oxford Research AS. (2008). Cluster Policy in Europe. A brief summary of cluster policies in 31 European countries. Europe Innova Cluster Mapping Project $2008 . \quad$ Retrieved from http://www.clusterobservatory.eu/system/modules/com.gridnine.opencms.modules.eco/providers/getpdf.j sp?uid $=100146$

Pavelková, D., et. al. (2013). Klastrové politiky a jejich vliv na rozvoj klastri a klastrových organizací. Praha: Linde nakladatelství s.r.o. ISBN 978-80-720-923-6.

Pessoa, A. (2012). Regional cluster policy: The Asian model vs. the OECD approach. MPRA Paper, University Library of Munich, Germany.

Polozhentseva, Y., Klevtsova, M. (2015). Instruments of Development of Cluster Policy: Stages, Models, International Practice. 22 ${ }^{\text {nd }}$ International Economic Conference - IECS 2015. Procedia Economics and Finance, 27, 529-537.

Porter, M. E. (2008). On Competition. Updated and Expanded Edition. Boston: Harvard Business School Publishing.

Porter, M. E. (1990). The competitive advantage of nations. 1st ed. New York: Free Press. ISBN-13: 978-0-684-84147-2.

Raines, P. (2001). The Cluster Approach and the Dynamics of Regional Policy-Making. Regional and Industrial Policy Research Paper, Number 47. The paper was presented at the Regional Studies Association International Conference, Regional Transitions, in Gdansk, Poland, on 16 September 2001.

Roelandt, T., den Hertog, P., Sinderden, J. v., \& Hove. N. v. d. (1999). Cluster analysis and cluster policy in the Netherlands. In OECD ed. Boosting innovation: the cluster approach. OECD, Paris.

Saublens, C. (2007). Regional Research Intensive Clusters and Science Parks. Brussels: European Commission.

Saxenian, A. (1994). Regional advantage: culture and competition in Silicon Valley and Route 128. Cambridge, MA: Harvard University Press.

Skokan, K., Poledníková, E., \& Stanícková, M. (2012). Establishment and growth of business clusters with public aid. Journal of Competitiveness, 4(3), doi:10.7441/joc.2012.03.02.

Sölvell, Ö., Lindqvist, G., \& Ketels, C. (2003). The Cluster Initiative Greenbook. Brommatryck AB, Stockholm.

Sternberg, R., Kiese, M., \& Stockinger, D. (2010). Cluster policies in the US and Germany: Varieties of capitalism perspective on two high-tech states. Environment and Planning C Government and Policy, 28(6), 1063-1082. doi:10.1068/c1019b.

Zeng, D. Z., (2011). China's Special Economic Zones and Industrial Clusters: Success and Challenges. World Bank. Retrieved from http://blogs.worldbank.org/developmenttalk/china-s-special-economic-zones-and-industrial-clusterssuccess-and-challenges. 


\section{APPENDIX}

Table 1

Cluster policy in Denmark, France, and Germany

\begin{tabular}{|c|c|c|c|}
\hline $\begin{array}{c}\text { Characteristic/ } \\
\text { Country }\end{array}$ & DENMARK & FRANCE & GERMANY \\
\hline Scope & $\begin{array}{l}\text { There is a low priority given to } \\
\text { national cluster policy in the country; } \\
\text { cluster programmes are formulated at } \\
\text { the regional level. }\end{array}$ & $\begin{array}{l}\text { National competitiveness cluster policy; } \\
\text { a short-term strategy since } 2005 \text {. }\end{array}$ & $\begin{array}{l}\text { A long-term strategy of cluster policy } \\
\text { was created in the } 1990 \text { s as national } \\
\text { framework for regional cluster } \\
\text { policies and system of clusters } \\
\text { funding. On the national level, the } \\
\text { High-Tech-Strategy has existed (since } \\
\text { 2006). On the federal state level, each } \\
\text { federal state (Bundesländer) has its } \\
\text { own long-term strategy for cluster } \\
\text { development. }\end{array}$ \\
\hline Approach & $\begin{array}{l}\text { The combination of both, top-down } \\
\text { and bottom-up model. As a type of } \\
\text { the top-down approach, here being } \\
\text { seen centres of excellence in specific } \\
\text { areas. }\end{array}$ & $\begin{array}{l}\text { Cluster policy within the Local } \\
\text { Productive System (LPS) was initially the } \\
\text { bottom-up approach, primarily based on } \\
\text { already existing networks of producers. } \\
\text { Les Pôles de compétitivité brought the } \\
\text { approach of top-down cluster policy. }\end{array}$ & $\begin{array}{l}\text { Cluster policy is implemented in both } \\
\text { types: the bottom-up without } \\
\text { significant political control, and the } \\
\text { top-down approach. About one-third } \\
\text { of the most competitive clusters is the } \\
\text { real bottom-up type that never } \\
\text { received public funding. }\end{array}$ \\
\hline Targeting & $\begin{array}{l}\text { In the early 2000s, Danish } \\
\text { government focused cluster support } \\
\text { to specific industries. The „,new } \\
\text { political approach" for the period } \\
2016-2018 \text { has been oriented on the } \\
\text { development of strong and excellent } \\
\text { clusters, promoting large and small } \\
\text { enterprises, building knowledge } \\
\text { networks between enterprises and } \\
\text { institutions. The main focus sectors } \\
\text { are high-technology, energy, and } \\
\text { environmental solutions. }\end{array}$ & $\begin{array}{l}\text { The new competitiveness policy has been } \\
\text { targeted at increasing regional } \\
\text { specialisation, strengthening the } \\
\text { competitiveness of French products on } \\
\text { global markets, enhancing cooperation } \\
\text { between universities, research centers, } \\
\text { and industrial firms, and promoting } \\
\text { innovation and modernisation of } \\
\text { industry in all sectors and regions. }\end{array}$ & $\begin{array}{l}\text { Policy support is focused on clusters } \\
\text { in selected (cutting-edge) fields of } \\
\text { technology, on stimulation of inter- } \\
\text { regional competition in the area of } \\
\text { technology and better functioning of } \\
\text { regional innovation systems. } \\
\text { Selected federal states high specialise } \\
\text { in high-tech manufacturing } \\
\text { (biotechnology, health and medical } \\
\text { science, new materials and chemistry, } \\
\text { micro, nano- and opto-technologies). }\end{array}$ \\
\hline Autonomy & $\begin{array}{l}\text { Cluster policy is integrated into policy } \\
\text { of innovation and technology for } \\
\text { science, and policy of regional } \\
\text { development (since 2006). }\end{array}$ & $\begin{array}{l}\text { Cluster policy is integrated into industrial } \\
\text { policy. }\end{array}$ & $\begin{array}{l}\text { Cluster policy is integrated into } \\
\text { technology policy. }\end{array}$ \\
\hline $\begin{array}{l}\text { Institutional } \\
\text { coordination }\end{array}$ & $\begin{array}{l}\text { Government bodies responsible for } \\
\text { the formulation of cluster policy at } \\
\text { the national level: the Ministry of } \\
\text { Science, Technology and Innovation, } \\
\text { the Ministry of the Environment, the } \\
\text { Ministry of Economic and Business } \\
\text { Affairs, the Ministry of Trade and } \\
\text { Industry. } \\
\text { Agencies established for support } \\
\text { cluster policy or cluster initiatives at } \\
\text { the national level: National Agency } \\
\text { for Enterprise and Construction, } \\
\text { Danish Forest and Nature Agency, } \\
\text { Danish Agency for Science } \\
\text { Technology and Innovation. Regional } \\
\text { Growth Forums work at the regional } \\
\text { level. }\end{array}$ & $\begin{array}{l}\text { At the national level, there are two } \\
\text { ministries; both have responsibility for } \\
\text { different aspects of cluster policy: the } \\
\text { Ministry of Economy, Finance and } \\
\text { Industry and the Ministry of the Interior. } \\
\text { There are also a number of } \\
\text { implementation agencies: the General } \\
\text { Directorate for Enterprise and the } \\
\text { Interministerial Delegation for Land } \\
\text { Planning and Competitiveness. } \\
\text { At the regional level, there are local } \\
\text { agencies known as Direction Régionale } \\
\text { des Entreprises, de la Concurrence, de la } \\
\text { Consommation, du Travail et de } \\
\text { l'Emploi (DIRECCTE). }\end{array}$ & $\begin{array}{l}\text { The leading Ministry is the Federal } \\
\text { Ministry of Economics and } \\
\text { Technology. Additional federal } \\
\text { ministries: the Federal Ministry of } \\
\text { Education and Research, and the } \\
\text { Federal Ministry of Transport, } \\
\text { Building and Urban Affairs. } \\
\text { There are several agencies with } \\
\text { responsibility for supporting cluster } \\
\text { development, e.g. the initiative } \\
\text { Networks for Competence in } \\
\text { Germany. }\end{array}$ \\
\hline $\begin{array}{l}\text { Policy } \\
\text { instruments }\end{array}$ & $\begin{array}{l}\text { Financial support for clusters comes } \\
\text { from the government's Innovation } \\
\text { Network Denmark programme (since } \\
\text { 2005). The programme of the } \\
\text { Regional Centres of Technology is } \\
\text { financed from the government, } \\
\text { covering } 60 \% \text { of expenditures for } 2-4 \\
\text { years. The total budget was DKK } 74 \\
\text { mil. Besides grant funding, the great } \\
\text { support is provided within technical } \\
\text { assistance for cluster management, } \\
\text { e.g. training, consultancy services; } \\
\text { regular meetings, workshops, }\end{array}$ & $\begin{array}{l}\text { Financial sources to explicitly support } \\
\text { clusters come from the national } \\
\text { budget.The public aid is based on calls } \\
\text { for tender leading to financial subsidies } \\
\text { with selection mechanism. Policy } \\
\text { implemented in } 2005 \text { is more costly than } \\
\text { previous ( } € 1.5 \text { bil. in each three-year } \\
\text { phase; the } € 500 \text { mil. per year represents } \\
5.5 \text { percent of the French national budget } \\
\text { allocated to universities and research). } \\
\text { The State provides support by setting up } \\
\text { national centres for research, networks } \\
\text { of innovation, public laboratories, }\end{array}$ & $\begin{array}{l}\text { Financial support has been provided } \\
\text { long-term to clusters in particular } \\
\text { fields to ensure that they are } \\
\text { sustainable: BioRegio ( } € 75 \text { mil.), } \\
\text { Innovative Regional Growth Cores } \\
\text { programme ( } € 150 \text { mil.), } \\
\text { Kompetenznetze Deutschland, ZIM- } \\
\text { Central Innovation Programme for } \\
\text { SME, Cutting-Edge cluster } \\
\text { competition. Financial aid is based on } \\
\text { applications. Indirect support is } \\
\text { provided by networking events, } \\
\text { consulting, training and seminars for }\end{array}$ \\
\hline
\end{tabular}




\begin{tabular}{|c|c|c|c|}
\hline & $\begin{array}{l}\text { matchmaking events, networking, } \\
\text { working group, etc. In } 2014 \text { Cluster } \\
\text { Excellence Denmark (CED) was } \\
\text { established as the national support } \\
\text { function for clusters. }\end{array}$ & $\begin{array}{l}\text { helping clusters find international } \\
\text { partners, pooling skills among SMEs, } \\
\text { providing actions and programmes for } \\
\text { training cluster actors. }\end{array}$ & $\begin{array}{l}\text { founders and employees within } \\
\text { clusters, certified laboratory } \\
\text { promotion. }\end{array}$ \\
\hline $\begin{array}{l}\text { Evaluation } \\
\text { system }\end{array}$ & $\begin{array}{l}\text { The existence of an evaluating system } \\
\text { of clusters, which are supported by } \\
\text { the Innovation Network Denmark } \\
\text { programme. CED disseminated the } \\
\text { EU's label system in Denmark as an } \\
\text { instrument for improving the quality } \\
\text { of the clusters' activities. }\end{array}$ & $\begin{array}{l}\text { Evaluation of clusters within Les Pôles } \\
\text { de compétitivité is based on } 72 \\
\text { indicators. The certification processes is } \\
\text { implemented at the national level by the } \\
\text { Interministerial Committee for Regional } \\
\text { Competitiveness. Another ongoing } \\
\text { evaluation is "Innovative cluster } \\
\text { company" label, launched by the Club } \\
\text { des PôlesMondiaux in partnership with } \\
\text { the Government, the French Private } \\
\text { Equity Association, France Angels and } \\
\text { others. }\end{array}$ & $\begin{array}{l}\text { Under clusters accreditation system } \\
\text { "Kompetenznetze Deutschland" } \\
(1998) \text {, clusters are classified } \\
\text { according to their quality. } \\
\text { Comparison of clusters is } \\
\text { implemented in close cooperation } \\
\text { with the Institute for Innovation and } \\
\text { Technology. For financial public } \\
\text { support within almost all cluster } \\
\text { programmes, clusters are selected } \\
\text { through a competitive audition } \\
\text { process. }\end{array}$ \\
\hline
\end{tabular}

Table 2

Cluster policy in China, Japan, and South Korea

\begin{tabular}{|c|c|c|c|}
\hline $\begin{array}{c}\text { Characteristic } \\
\text { /Country }\end{array}$ & CHINA & JAPAN & SOUTH KOREA \\
\hline Scope & $\begin{array}{l}\text { The strong support of clusters comes } \\
\text { from local governments. In 2000, the } \\
\text { Government of Guangdong Province } \\
\text { introduced the Specialised Towns } \\
\text { Program (with slogan ,one product } \\
\text { per village and one sector per town”) } \\
\text { to enhance the development of } \\
\text { lagging areas (The 13th Five Year Plan } \\
\text { 2016-2020). The cluster concept is } \\
\text { implemented through special } \\
\text { economic zones (SEZs), science } \\
\text { parks, and industrial clusters. }\end{array}$ & $\begin{array}{l}\text { „Knowledge Cluster Initiative” launched } \\
\text { in } 2002 \text {, was carried out with the support } \\
\text { of the central government on the national } \\
\text { level. Nowadays, a crucial role in the } \\
\text { creation of clusters has local } \\
\text { governments (prefectural and municipal } \\
\text { authorities). The active process of cluster } \\
\text { policy began in } 2001 \text { on the basis of the } \\
\text { "Plan for Development of Science and } \\
\text { Technology". In } 2013 \text {, Japan accepted } \\
\text { the Strategy of the Development of } \\
\text { Science, Technology and Innovation. }\end{array}$ & $\begin{array}{l}\text { The Government operated the } \\
\text { Regional Strategic Industry Promotion } \\
\text { Project in } 4 \text { regions (from 1999), the } \\
\text { national first systematic cluster } \\
\text { development policy to achieve } \\
\text { regional economic development. In } \\
2002 \text { the Strategic Regional Industry } \\
\text { Plan (2002-2007) for } 9 \text { regions was } \\
\text { implemented to support two to three } \\
\text { strategic industries for each city and } \\
\text { province. }\end{array}$ \\
\hline Approach & $\begin{array}{l}\text { In China, the approach to cluster } \\
\text { policy is typically top-down. }\end{array}$ & $\begin{array}{l}\text { Cluster policy in Japan is implemented by } \\
\text { the top-down approach. }\end{array}$ & $\begin{array}{l}\text { Cluster policy in South Korea is } \\
\text { government-led; it is "heavy handed" } \\
\text { top-down cluster policy. }\end{array}$ \\
\hline Targeting & $\begin{array}{l}\text { The programme Specialise Towns is } \\
\text { encouraged with the aim to increase } \\
\text { technological upgrading and } \\
\text { innovation by means of increased } \\
\text { specialisation. } \\
\text { Clusters operate mainly in the labor- } \\
\text { intensive manufacturing sectors } \\
\text { (advanced avionics, electronic } \\
\text { systems, communications systems, } \\
\text { new materials, environmental } \\
\text { protection, advanced manufacturing } \\
\text { and transportation systems). }\end{array}$ & $\begin{array}{l}\text { The Japanese knowledge cluster concept } \\
\text { is concentrated on revitalising regional } \\
\text { economies. Cluster policy encourages the } \\
\text { development of highly specialised } \\
\text { regions. The ongoing programme } \\
\text { "Knowledge Cluster Initiative" } \\
\text { stimulates the development of clusters in } \\
\text { the } 18 \text { regions with the focus on } \\
\text { automotive and machine industries, } \\
\text { electrical, nanotechnology, robotics, } \\
\text { biological production, and ecology. }\end{array}$ & $\begin{array}{l}\text { The policy goal of the Programme of } \\
\text { Industrial Complex Clusters is } \\
\text { narrowing the regional gaps and } \\
\text { building the regional innovation } \\
\text { system. The Programm currently } \\
\text { targets at } 31 \text { industrial complexes } \\
\text { selected as "strategic" with the focus } \\
\text { on building infrastructure and the } \\
\text { industry-academia-research } \\
\text { networking and selected industries } \\
\text { (e.g. digital contents, ICT, auto parts, } \\
\text { electronics, metal machine materials, } \\
\text { mobile, medical devices, } \\
\text { mechatronics). }\end{array}$ \\
\hline Autonomy & $\begin{array}{l}\text { The creation of industrial clusters is a } \\
\text { basic aspect of industrial policy in } \\
\text { China. }\end{array}$ & $\begin{array}{l}\text { Cluster policy is non-separate, is a part of } \\
\text { the economic and industrial policy. }\end{array}$ & $\begin{array}{l}\text { Cluster policy is integrated into } \\
\text { innovation policy. }\end{array}$ \\
\hline $\begin{array}{l}\text { Institutional } \\
\text { coordination }\end{array}$ & $\begin{array}{l}\text { The National Development and } \\
\text { Reform Commission, the Department } \\
\text { of Science and Technology of } \\
\text { Guangdong Government. }\end{array}$ & $\begin{array}{l}\text { The Ministry of Education, Culture, } \\
\text { Sports, Science and Technology } \\
\text { (MEXT), the Ministry of Economy, } \\
\text { Trade and Industry (METI) with its unit } \\
\text { - the Small and Medium Enterprise } \\
\text { Agency, prefectures. }\end{array}$ & $\begin{array}{l}\text { The government strongly supports } \\
\text { clusters through several ministries: the } \\
\text { Ministry of Trade, Industry and } \\
\text { Energy, the Ministry of Land, } \\
\text { Infrastructure, and Transport, the } \\
\text { Ministry of Environment, the Ministry } \\
\text { of Employment and Labour, the } \\
\text { Ministry of Culture, Sports, and } \\
\text { Tourism and the Ministry of } \\
\text { Education, Science and Technology. } \\
\text { Other supporting institutions: The } \\
\text { Presidential Committee on Balanced } \\
\text { National Development, Korea } \\
\text { Industrial Complex Corporation }\end{array}$ \\
\hline
\end{tabular}




\begin{tabular}{|c|c|c|c|}
\hline & & & $\begin{array}{l}\text { (KICOX), the Business Growth } \\
\text { Support Center. }\end{array}$ \\
\hline $\begin{array}{l}\text { Policy } \\
\text { instruments }\end{array}$ & $\begin{array}{l}\text { Financial funds are directed to } \\
\text { officially recognised "specialised } \\
\text { towns". The key integral part of } \\
\text { cluster development is the generic } \\
\text { infrastructure development, e.g. road } \\
\text { transport network, regular electricity. } \\
\text { Indirect support goes to enhancing } \\
\text { anchor firms as cluster members } \\
\text { (mainly MNCs), support of start-ups, } \\
\text { attracting foreign firms and highly } \\
\text { skilled workers, grants to firms, loans } \\
\text { and guarantees below market rates, tax } \\
\text { exemption. }\end{array}$ & $\begin{array}{l}\text { Instruments of financial stimulation: tax } \\
\text { credits for SMEs conducting R\&D and } \\
\text { innovation activities. Financial support is } \\
\text { provided as a full funding scheme } \\
\text { (including partial funding by local } \\
\text { authorities). The government invested } \\
\text { approx. } 55 \text { billion yen in R\&D support } \\
\text { under the Industrial Cluster Project (ICP, } \\
\text { 1.phase 2001-2004), only } 2 \text { billion yen in } \\
\text { indirect support, such as networking, } \\
\text { development of incubators, small } \\
\text { business support, fostering highly } \\
\text { specialized HR, establishment of the } \\
\text { Regional Cluster Promotion Association. }\end{array}$ & $\begin{array}{l}\text { The Government of Korea launched } \\
\text { the Programme of Industrial Complex } \\
\text { Clusters (in 2005), The Strategic } \\
\text { Regional Industry Plan (2002-2007). } \\
\text { Annual amount of government } \\
\text { support is over KRW } 1 \text { trillion (till } \\
\text { 2018). The budget of the } 3^{\text {rd }} \text { phase of } \\
\text { the Program was KRW } 59.7 \text { billion for } \\
\text { 2015. Korea's policy tends use firm } \\
\text { subsidies, investment in hard } \\
\text { infrastructure, training initiatives, and } \\
\text { the great accent is placed on } \\
\text { developing incubators. }\end{array}$ \\
\hline $\begin{array}{l}\text { Evaluation } \\
\text { system }\end{array}$ & $\begin{array}{l}\text { Regional government experts } \\
\text { acknowledge the town with label } \\
\text { "Specialised Town", which receive } \\
\text { funding. These towns have to meet } \\
\text { selected criteria (e.g. } 30 \% \text { of its } \\
\text { industrial output has to been } \\
\text { concentrated in one industry - } \\
\text { "specialised sector"). }\end{array}$ & $\begin{array}{l}\text { The existence of the assessment of } \\
\text { cluster programmes by the Industrial } \\
\text { Cluster Study Group, e.t. for financial } \\
\text { support within ICP, METI has selected } \\
\text { regional clusters based on comparative } \\
\text { advantages. }\end{array}$ & $\begin{array}{l}\text { In } 2007 \text { "Korean cluster evaluation } \\
\text { system" was established to benchmark } \\
\text { performance of clusters. Within the } \\
\text { Program of Industrial Complex } \\
\text { Clusters, the cluster development } \\
\text { model "Mini-clusters" (small-sized } \\
\text { networking groups of enterprises) was } \\
\text { developed. The purpose of the } 3^{\text {rd }} \\
\text { phase of the Program (from 2013) is } \\
\text { the promotion of the world's best } \\
\text { innovative cluster and creation of the } \\
\text { self-sustainable cluster ecosystem. }\end{array}$ \\
\hline
\end{tabular}

